CLINICAL STUDY

\title{
Decrement of postprandial insulin secretion determines the progressive nature of type-2 diabetes
}

\author{
Wan Sub Shim, Soo Kyung Kim ${ }^{3}$, Hae Jin $\mathrm{Kim}^{4}$, Eun Seok Kang ${ }^{2}$, Chul Woo Ahn ${ }^{1,2}$, Sung Kil $\mathrm{Lim}^{1,2}$, \\ Hyun Chul Lee ${ }^{1,2}$ and Bong Soo Cha ${ }^{1,2}$ \\ Department of Internal Medicine, Inha University College of Medicine, Incheon, Korea, ${ }^{1}$ Brain Korea 21, Project for Medical Science and ${ }^{2}$ Department of \\ Internal Medicine, Yonsei University College of Medicine, Seoul, Korea, ${ }^{3}$ Department of Internal Medicine, College of Medicine, Pochon CHA University, \\ Sungnam, Kyunggi-do, Korea and ${ }^{4}$ Department of Endocrinology and Metabolism, Ajou University School of Medicine, Suwon, Korea \\ (Correspondence should be addressed to B S Cha; Email: bscha@yumc.yonsei.ac.kr)
}

\begin{abstract}
Objective: Type-2 diabetes is a progressive disease. However, little is known about whether decreased fasting or postprandial pancreatic $\beta$-cell responsiveness is more prominent with increased duration of diabetes. The aim of this study was to evaluate the relationship between insulin secretion both during fasting and $2 \mathrm{~h}$ postprandial, and the duration of diabetes in type- 2 diabetic patients.

Design: Cross-sectional clinical investigation.

Methods: We conducted a meal tolerance test in 1466 type-2 diabetic patients and calculated fasting $\left(M_{0}\right)$ and postprandial $\left(M_{1}\right) \beta$-cell responsiveness.

Results: The fasting C-peptide, postprandial C-peptide, $M_{0}$, and $M_{1}$ values were lower, but $\mathrm{HbA}_{1 \mathrm{c}}$ values were higher, in patients with diabetes duration $>10$ years than those in other groups. There was no difference in the $\mathrm{HbA}_{1 \mathrm{c}}$ levels according to the tertiles of their fasting C-peptide level. However, in a group of patients with highest postprandial C-peptide tertile, the $\mathrm{HbA}_{1 \mathrm{c}}$ values were significantly lower than those in other groups. After adjustment of age, sex, and body mass index (BMI), the duration of diabetes was found to be negatively correlated with fasting C-peptide $(\gamma=-0.102)$, postprandial Cpeptide $(\gamma=-0.356), M_{0}(\gamma=-0.263)$, and $M_{1}(\gamma=-0.315 ; P<0.01$ respectively $)$. After adjustment of age, sex, and BMI, $\mathrm{HbA}_{1 \mathrm{c}}$ was found to be negatively correlated with postprandial $\mathrm{C}$ peptide $(\gamma=-0.264), M_{0}(\gamma=-0.379)$, and $M_{1}(\gamma=-0.522)$, however, positively correlated with fasting C-peptide $\left(\gamma=0.105 ; P<0.01\right.$ respectively). In stepwise multiple regression analysis, $M_{0}, M_{1}$, and homeostasis model assessment for insulin resistance (HOMA-IR) emerged as predictors of $\mathrm{HbA}_{\mathrm{lc}}$ after adjustment for age, sex, and BMI $\left(R^{2}=0.272,0.080\right.$, and 0.056 respectively $)$.

Conclusions: With increasing duration of diabetes, the decrease of postprandial insulin secretion is becoming more prominent, and postprandial $\beta$-cell responsiveness may be a more important determinant for glycemic control than fasting $\beta$-cell responsiveness.
\end{abstract}

European Journal of Endocrinology 155 615-622

\section{Introduction}

A variety of oral glucose and meal tolerance tests have extensively been used to diagnose type-2 diabetes mellitus in a clinical setting. The oral load results in a typical postprandial exposure of the pancreas to glucose, nutrient (protein and fat), and gut and vagal hormones. The measurement of pancreatic responsiveness, therefore, closely reflects the ability of the pancreas to produce insulin under normal physiological conditions (1).

The results of United Kingdom Prospective Diabetes Study indicate that, in the group with intensive treatment, it took 6 and 4 years before the fasting plasma glucose level and $\mathrm{HbA}_{1 \mathrm{c}}$ returned to the pretherapy level respectively, and the difference may reflect increasing postprandial hyperglycemia (2). Relative contribution of fasting and postprandial plasma glucose to the $\mathrm{HbA}_{1 \mathrm{c}}$ remains to be uncertain; some researchers support fasting plasma glucose values to be a better predictor for the overall glycemia as reflected by the $\mathrm{HbA}_{1 \mathrm{c}}$ value (3), whereas others favor postprandial plasma glucose as a better predictor (4-6). Results from studies aimed at reducing postprandial glycemia support the latter claim $(7,8)$. Therefore, postprandial glucose concentration appears to contribute more or at least equally to the overall glycemia than fasting glucose concentration. Furthermore, decreased postprandial insulin response most plausibly explains elevated fasting plasma glucose, $\mathrm{HbA}_{1 \mathrm{c}}$, and glucose responses to meal in newly presenting type- 2 diabetic patients (9).

Todate, most studies on the $\beta$-cell function in type- 2 diabetes had some limitations: (i) only fasting insulin secretion was measured (2), or (ii) postprandial insulin secretion was measured in a small number of patients 
(9). There have been few studies on the association of fasting and postprandial 2-h insulin secretion with the duration of diabetes and glycemic control in a large number of type-2 diabetic patients, whose durations of diabetes are varied. Therefore, we undertook to examine the relationship of insulin secretion during fasting and postprandial $2 \mathrm{~h}$ with the duration of diabetes and glycemic control in Korean type- 2 diabetic patients.

\section{Subjects and methods}

\section{Study subjects}

Randomly selected type-2 diabetic patients $(n=1466$, 810 males and 656 females), who visited the Diabetes Center at Severance Hospital, Yonsei University Medical Center from June 2002 to April 2005 for glycemic control were enrolled in this study. Their treatment methods were not changed during the last 3 months. Patients presenting with symptoms suggestive of type-1 diabetes, defined as diabetic ketoacidosis, acute presentation with heavy ketonuria $(3+)$, or continuous requirement of insulin within 1 year of diagnosis were excluded. Patients with glutamic acid decarboxylase antibody positivity were excluded. Patients who had taken steroid or renal impairment (plasma $\mathrm{Cr}$ higher than $1.5 \mathrm{mg} / \mathrm{dl}$ ) were also excluded. Furthermore, 54 patients with insulin treatment were also included. The insulin concentration data on patients with insulin treatment were excluded from the analysis. The Ethics Committee of Yonsei University College of Medicine, Seoul, approved this study, and informed consent was obtained from each subject.

\section{Methods}

Subjects' height and weight were measured to the nearest $0.1 \mathrm{~cm}$ and $0.1 \mathrm{~kg}$ respectively. They were allowed to wear light clothing but not to wear shoes. Body mass index (BMI) was calculated as weight $(\mathrm{kg})$ over the square of the height $\left(\mathrm{m}^{2}\right)$. Blood samples were collected after 12-h fasting. Fasting glucose was measured by the glucose oxidase method. $\mathrm{HbA}_{1 \mathrm{c}}$ was analyzed by HPLC (Variant II; Bio-Rad; coefficient of variation $(\mathrm{CV})=2.1 \%)$. Insulin concentration was measured by IRMA (RIABEAD II kit, Abbott, Japan; intra-assay CV $1.2-1.9 \%$, inter-assay CV $1.4-3.3 \%$ ). The concentration of C-peptide was measured by RIA (DiaSorin, Stillwater, MN, USA; CV $=2.7 \%$ ).

After obtaining fasting blood samples, patients were allowed to eat one type of meal selected from a few standardized meals (total $823 \pm 132 \mathrm{kcal}$ containing, protein $17.7 \pm 4.6 \%$, fat $16.3 \pm 6.4 \%$, and carbohydrate $65.9 \pm 10.0 \%$ ), while medications were taken as usual. The concentration of serum glucose, insulin, and $\mathrm{C}$-peptide was measured $2 \mathrm{~h}$ after the meal. Currently used oral hypoglycemic agents were examined: one tablet of sulfonylurea was considered as $80 \mathrm{mg}$ gliclazide or $2 \mathrm{mg}$ glimepiride (10), and one tablet of biguanide was considered as $500 \mathrm{mg}$ metformin. With regard to $\alpha$-glucosidase inhibitor, $0.2 \mathrm{mg}$ voglibose were considered to be equivalent to $100 \mathrm{mg}$ acarbose (11). Rosiglitazone (4 mg) and pioglitazone (15 mg) were considered to be equivalent $(12,13)$.

$\Delta$ Insulin concentration was defined as the postprandial 2 -h insulin concentration minus fasting insulin concentration, and $\Delta C$-peptide concentration as the postprandial 2-h C-peptide concentration minus fasting $\mathrm{C}$-peptide concentration.

Fasting $\beta$-cell responsiveness $\left(M_{0}\right)$ represents the ability of fasting glucose to stimulate $\beta$-cell secretion (1) and postprandial $\beta$-cell responsiveness $\left(M_{1}\right)$ represents the ability of postprandial glucose to step up $\beta$-cell secretion (1), and they were calculated using the formula of Hovorka et al. (1) with some modification:

$$
\begin{aligned}
M_{0}= & 100 \times \text { fasting } \mathrm{C}-\text { peptide }(\mu \mathrm{g} / \mathrm{l}) / \text { fasting glucose } \\
& \text { concentration }(\mathrm{mg} / \mathrm{dl}) \\
M_{1}= & 100(\text { postprandial } 2-\mathrm{h} \mathrm{C}-\text { peptide concentration }(\mu \mathrm{g} / \mathrm{l}) \\
& - \text { fasting } \mathrm{C}-\text { peptide concentration }(\mu \mathrm{g} / \mathrm{l})) /(\text { postprandial } \\
& \text { 2-h glucose concentration }(\mathrm{mg} / \mathrm{dl})-\text { fasting glucose } \\
& \text { concentration }(\mathrm{mg} / \mathrm{dl}))
\end{aligned}
$$

As an indicator of insulin resistance, this study used the homeostasis model assessment for insulin resistance (HOMA-IR), which was calculated as follows (14):

$$
\begin{aligned}
\text { HOMA-IR }= & (\text { fasting insulin }(\mu \mathrm{U} / \mathrm{ml}) \\
& \times \text { fasting glucose }(\mathrm{mmol} / \mathrm{l}) / 22.5)
\end{aligned}
$$

According to the duration of diabetes, the subjects were divided into three groups; shorter than 5 years, from 5 years to less than 10 years, and longer than 10 years for analysis. According to their fasting, postprandial and $\Delta C$-peptide concentrations, the subjects were divided into three groups. After adjustment for age, sex, and BMI, the correlation between duration of diabetes, $\mathrm{HbA}_{1 \mathrm{c}}$, and other metabolic parameters was analyzed.

\section{Statistical analysis}

Statistical analyses were performed using SPSS software (version 13.0; SPSS, Inc., Chicago, IL, USA). All continuous variables are expressed as mean \pm s.D., except insulin, C-peptide, HOMA-IR, $M_{0}$, and $M_{1}$, which are described as median and range and were log-transformed to accommodate skewing of the distribution. Comparisons between groups classified by the duration of diabetes, fasting C-peptide, postprandial C-peptide, and $\Delta$ C-peptide value were performed by using ANOVA followed by post hoc testing 
with Tukey's test. The $\chi^{2}$ test was used for categorical variables. Partial Pearson's correlation coefficiency between the duration of diabetes and $\mathrm{HbA}_{1 \mathrm{c}}$, and other metabolic parameters were preformed after adjustment of age, sex, and BMI. Stepwise multiple regression analysis with $\mathrm{HbA}_{1 \mathrm{c}}$ as a dependent variable was performed. Variables of age, gender, BMI, $M_{0}, M_{1}$, and HOMA-IR were analyzed as independent variables. A two-sided value of $P<0.05$ was considered to be statistically significant.

\section{Results}

\section{Clinical characteristics of patients}

The mean age of patients was $55.0 \pm 11.5$ years, the mean duration of diabetes was $5.0 \pm 5.7$ years, mean BMI was $25.4 \pm 3.2 \mathrm{~kg} / \mathrm{m}^{2}$, and the median concentrations of fasting, postprandial, and $\Delta \mathrm{C}$-peptide were $1.54(0.54-6.70) \mu \mathrm{g} / \mathrm{l}, 3.74(1.01-17.63) \mu \mathrm{g} / \mathrm{l}$, and $2.11(0.01-14.84) \mu \mathrm{g} / \mathrm{l}$ respectively.

\section{Clinical characteristics according to the duration of diabetes}

In the group with diabetes for longer than 10 years, their age, and $\mathrm{HbA}_{1 \mathrm{c}}$ value were higher, and their BMI, fasting $\mathrm{C}$-peptide, postprandial $\mathrm{C}$-peptide, fasting insulin, postprandial insulin, $\Delta$ insulin, $\Delta$ C-peptide, fasting $\beta$-cell responsiveness, and postprandial $\beta$-cell responsiveness were lower than those in other groups. The number of tablets of sulfonylurea, metformin, $\alpha$-glucosidase inhibitor, and thiazolidinedione used were higher than those in the group with diabetes for less than 5 years. Furthermore, the prevalence of patients with insulin treatment was higher (Table 1).

\section{Clinical characteristics according to the ter- tiles of fasting C-peptide level}

In the group with highest fasting $\mathrm{C}$-peptide tertile, their duration of diabetes was shortest. Their BMI, fasting insulin, postprandial insulin, postprandial C-peptide, $\Delta$ insulin, $\Delta C$-peptide, fasting $\beta$-cell responsiveness, and postprandial $\beta$-cell responsiveness were higher than those of other groups. However, the concentrations of fasting glucose, postprandial glucose, and $\mathrm{HbA}_{1 \mathrm{c}}$ were not different among the three groups (Table 2).

\section{Clinical characteristics according to the tertiles of postprandial C-peptide level}

In the group with highest postprandial C-peptide tertile, their duration of diabetes was shorter, and their BMI, fasting insulin, postprandial insulin, fasting C-peptide, $\Delta$ insulin, $\Delta$ C-peptide, fasting $\beta$-cell responsiveness, and postprandial $\beta$-cell responsiveness were higher than those of the other two groups. However, the

Table 1 Clinical characteristics according to the duration of diabetes. Data are expressed as mean \pm s.D. Insulin, C-peptide, $M_{0}$, and $M_{1}$ values are described as median (range) values.

\begin{tabular}{|c|c|c|c|}
\hline Duration of diabetes (years) & $<5$ & $\geq 5-<10$ & $\geq 10$ \\
\hline$n$ & 887 & 240 & 339 \\
\hline Age (years) & $52.3 \pm 11.9$ & $55.8 \pm 10.1^{*}$ & $59.9 \pm 9.6^{\dagger \ddagger}$ \\
\hline Sex (female \%) & $4 \overline{2}$ & 48 & $\overline{48}$ \\
\hline BMI $\left(\mathrm{kg} / \mathrm{m}^{2}\right)$ & $25.7 \pm 3.3$ & $25.3 \pm 2.9$ & $24.5 \pm 3.0^{\dagger \ddagger}$ \\
\hline Fasting glucose (mmol/l) & $7.50 \pm 2.09$ & $8.63 \pm 2.38^{*}$ & $8.93 \pm 2.59^{\dagger}$ \\
\hline PP 2-h glucose (mmol/l) & $11.54 \pm 4.24$ & $13.76 \pm 4.18^{*}$ & $14.32 \pm 4.53^{\dagger}$ \\
\hline $\mathrm{HbA}_{1 \mathrm{c}}(\%)$ & $7.5 \pm 1.6$ & $8.0 \pm 1.5^{*}$ & $8.4 \pm 1.5^{\dagger \ddagger}$ \\
\hline Fasting insulin (pmol/l) & $51.1(4.8-234.8)$ & $50.3(10.0-212.5)$ & $42.5(8.4-225.7)^{\dagger \ddagger}$ \\
\hline PP 2-h insulin (pmol/l) & $267.1(17.7-2152.5)$ & $194.2(26.3-1123.1)^{\star}$ & $150.2(20.0-900.2)^{\dagger \ddagger}$ \\
\hline Fasting C-peptide ( $\mu \mathrm{g} / \mathrm{l})$ & $1.60(0.69-5.70)$ & $1.56(0.70-6.70)$ & $1.39(0.54-3.72)^{f \neq}$ \\
\hline PP 2-h C-peptide $(\mu \mathrm{g} / \mathrm{l})$ & $4.21(1.03-17.63)$ & $3.43(1.27-14.69)^{*}$ & $2.90(1.01-8.50)^{\dagger \ddagger}$ \\
\hline$\Delta$ Insulin $(\mathrm{pmol} / \mathrm{l})$ & $210.9(2.7-1972.2)$ & $144.4(7.3-984.5)^{*}$ & $103.5(0.5-760.4)^{\dagger \ddagger}$ \\
\hline$\Delta \mathrm{C}$-peptide $(\mu \mathrm{g} / \mathrm{l})$ & $2.50(0.02-14.84)^{\prime}$ & $1.88(0.05-7.99)^{*}$ & $1.49(0.01-7.22)^{\dagger \ddagger}$ \\
\hline$M_{0}$ & $1.25(0.35-6.79)$ & $1.02(0.42-3.99)^{*}$ & $0.91(0.27-3.14)^{\dagger \ddagger}$ \\
\hline$M_{1}$ & $3.30(-481.0-372.0)$ & $1.88(-252.0-67.7)^{\star}$ & $1.42(-81.0-53.3)^{\dagger \ddagger}$ \\
\hline No. of tablet of sulfonylurea & $0.18 \pm 0.39$ & $0.83 \pm 0.68^{*}$ & $1.16 \pm 0.87^{\dagger \ddagger}$ \\
\hline No. of tablet of metformin & $0.70 \pm 1.01$ & $1.46 \pm 1.21^{*}$ & $1.37 \pm 1.21^{\dagger}$ \\
\hline No. of tablet of AGL & $0.09 \pm 0.43$ & $0.47 \pm 1.16^{*}$ & $0.57 \pm 1.10^{\dagger}$ \\
\hline No. of tablet of TZD & $0.05 \pm 0.19$ & $0.16 \pm 0.37^{*}$ & $0.16 \pm 0.35^{\dagger}$ \\
\hline No. of tablet of other OHA & $0.04 \pm 0.29$ & $0.02 \pm 0.27$ & $0.08 \pm 0.45$ \\
\hline Prevalence of insulin user (\%) & $0 . \overline{2}$ & 2.5 & $13.6^{\dagger \ddagger}$ \\
\hline
\end{tabular}

BMI, body mass index; PP, postprandial; $M_{0}$, fasting $\beta$-cell responsiveness; $M_{1}$, postprandial $\beta$-cell responsiveness; AGL, $\alpha$-glucose inhibitor; TZD, thiolidinedione; OHA, oral hypoglycemic agents; HOMA-IR, homeostatic model assessment of insulin resistance. $P$ value was obtained from the ANOVA (post hoc and Tukey's test). ${ }^{*} P<0.05$ between groups (duration of diabetes below 5 years versus duration of diabetes above 5 years and below 10 years). ${ }^{\dagger} P<0.05$ between groups (duration of diabetes below 5 years versus duration of diabetes above 10 years). ${ }^{\ddagger} P<0.05$ between groups (duration of diabetes above 5 years and below 10 years versus duration of diabetes above 10 years). 
Table 2 Clinical characteristics according to the tertile of fasting C-peptide level. Data are expressed as mean \pm s.D. Insulin, C-peptide, $M_{0}$, and $M_{1}$ values are described as median (range) values.

\begin{tabular}{|c|c|c|c|}
\hline Tertile of fasting C-peptide & Tertile 1 & Tertile 2 & Tertile 3 \\
\hline$n$ & 489 & 493 & 484 \\
\hline C-peptide range $(\mu \mathrm{g} / \mathrm{l})$ & $0.54-1.33$ & $1.34-1.83$ & $1.84-6.70$ \\
\hline Age (years) & $56.0 \pm 10.7$ & $55.1 \pm 11.5$ & $54.0 \pm 12.1^{\dagger}$ \\
\hline Sex (female \%) & $5 \overline{0}$ & $4 \overline{2}^{*}$ & 43 \\
\hline Duration of diabetes (years) & $6.3 \pm 6.5$ & $5.0 \pm 5.6^{\star}$ & $3.7 \pm 4.6^{\dagger \ddagger}$ \\
\hline BMI $\left(\mathrm{kg} / \mathrm{m}^{2}\right)$ & $24.1 \pm 2.8$ & $25.3 \pm 2.9^{*}$ & $26.7 \pm 3.3^{\dagger \ddagger}$ \\
\hline Fasting glucose $(\mathrm{mmol} / \mathrm{l})$ & $7.85 \pm 2.51$ & $8.12 \pm 2.30$ & $8.08 \pm 2.21$ \\
\hline PP 2-h glucose (mmol/l) & $12.38 \pm 4.71$ & $12.56 \pm 4.40$ & $12.66 \pm 4.31$ \\
\hline $\mathrm{HbA}_{1 \mathrm{c}}(\%)$ & $7.7 \pm 1.6$ & $7.8 \pm 1.6$ & $7.9 \pm 1.5$ \\
\hline Fasting insulin (pmol/l) & $28.6(4.8-219.0)$ & $46.2(8.8-153.5)^{\star}$ & $74.4(10.9-234.8)^{\dagger \ddagger}$ \\
\hline PP 2-h insulin (pmol/l) & $158.4(17.7-1123.1)$ & $211.6(25.8-1486.1)^{\star}$ & $326.4(25.6-2152.5)^{\dagger \ddagger}$ \\
\hline PP 2-h C-peptide ( $\mu \mathrm{g} / \mathrm{l})$ & $2.86(1.01-10.70)$ & $3.57(1.39-9.54)^{*}$ & $5.19(2.07-17.63)^{f \neq}$ \\
\hline$\Delta$ Insulin $(\mathrm{pmol} / \mathrm{l})$ & $120.5(0.9-984.5)$ & $160.5(0.5-1411.9)^{*}$ & $251.1(0.9-1972.2)^{\dagger \ddagger}$ \\
\hline$\Delta$ C-peptide $(\mu \mathrm{g} / \mathrm{l})$ & $1.79(0.01-9.70)$ & $2.03(0.05-7.81)^{\star}$ & $2.73(0.02-14.84)^{\dagger \ddagger}$ \\
\hline$M_{0}$ & $0.80(0.27-1.74)$ & $1.14(0.56-2.53)^{\star}$ & $1.71(0.75-6.79)^{\dagger \neq}$ \\
\hline$M_{1}$ & $1.94(-252.0-176.5)$ & $2.24(-161.5-372.0)$ & $3.11(-481.0-332.0)^{\dagger \neq}$ \\
\hline HOMA-IR & $1.36(0.31-9.11)$ & $2.24(0.31-10.77)^{*}$ & $3.64(0.35-16.66)^{\dagger+}$ \\
\hline No. of tablet of sulfonylurea & $0.47 \pm 0.63$ & $0.49 \pm 0.65$ & $0.44 \pm 0.64$ \\
\hline No. of tablet of metformin & $1.02 \pm 1.13$ & $1.03 \pm 1.13$ & $0.87 \pm 1.15$ \\
\hline No. of tablet of AGL & $0.27 \pm 0.76$ & $0.25 \pm 0.73$ & $0.24 \pm 0.74$ \\
\hline No. of tablet of TZD & $0.15 \pm 0.31$ & $0.07 \pm 0.22^{*}$ & $0.07 \pm 0.23^{*}$ \\
\hline No. of tablet of other OHA & $0.04 \pm 0.30$ & $0.04 \pm 0.29$ & $0.05 \pm 0.36$ \\
\hline Prevalence of insulin user (\%) & $6 . \overline{7}$ & $2.8^{*}$ & $1.4^{*}$ \\
\hline
\end{tabular}

$\mathrm{BMI}$, body mass index; PP, postprandial; $M_{0}$, fasting $\beta$-cell responsiveness; $M_{1}$, postprandial $\beta$-cell responsiveness; HOMA-IR, homeostatic model assessment of insulin resistance; AGL, $\alpha$-glucose inhibitor; TZD, thiolidinedione; OHA, oral hypoglycemic agents. $P$ value was obtained from the ANOVA (post hoc and Tukey's test). ${ }^{\star} P<0.05$ between groups (tertile 1 versus tertile 2 ). ${ }^{\dagger} P<0.05$ between groups (tertile 1 versus tertile 3 ). ${ }^{\ddagger} P<0.05$ between groups (tertile 2 versus tertile 3 ).

concentrations of fasting glucose and $\mathrm{HbA}_{1 \mathrm{c}}$ were lower than those of other groups, although they used the lowest dosage of sulfonylurea and metformin among the three groups. The prevalence of patients with insulin treatment was lower (Table 3).

\section{Clinical characteristics according to the tertiles of $\boldsymbol{\Delta}$ C-peptide level}

In the group with highest $\Delta \mathrm{C}$-peptide tertile, subjects' duration of diabetes was shorter, and their BMI, fasting insulin, postprandial insulin, fasting C-peptide, postprandial $C$-peptide, $\Delta$ insulin, fasting $\beta$-cell responsiveness, and postprandial $\beta$-cell responsiveness were higher than those of the other two groups. However, the concentrations of fasting glucose, postprandial glucose, and $\mathrm{HbA}_{1 \mathrm{c}}$ were lower than those of the other groups, although they used the lowest dosage of sulfonylurea and metformin among the three groups. The prevalence of patients with insulin treatment was lower (Table 4).

\section{The distribution of $C$-peptide according to the duration of diabetes}

The distribution of fasting C-peptide, postprandial C-peptide, and $\Delta \mathrm{C}$-peptide concentrations according to the duration of diabetes were shown in Fig. $1 \mathrm{~A}-\mathrm{C}$ respectively.

\section{Relationship between the duration of diabetes and other metabolic parameters}

After adjustment of age, sex, and BMI, the duration of diabetes was found to be negatively correlated with fasting insulin $(\gamma=-0.098)$, postprandial insulin $(\gamma=-0.315)$, fasting C-peptide $(\gamma=-0.102)$, postprandial C-peptide $(\gamma=-0.356), \quad \Delta \quad$ insulin $(\gamma=-0.309), \Delta$ C-peptide $(\gamma=-0.358)$, fasting $\beta$-cell responsiveness $(\gamma=-0.263)$, and postprandial $\beta$-cell responsiveness $(\gamma=-0.315)$, but positively with fasting glucose $(\gamma=0.272)$, postprandial glucose $(\gamma=$ $0.241)$, and $\mathrm{HbA}_{1 \mathrm{c}}(\gamma=0.210)(P<0.001$, except for fasting insulin $P<0.01)$.

\section{Relationship between $H b A_{1 c}$ and other metabolic parameters}

After adjustment of age, sex, and BMI, $\mathrm{HbA}_{1 \mathrm{c}}$ was found to be positively correlated with the duration of diabetes $(\gamma=0.210)$, fasting glucose $(\gamma=0.704)$, postprandial glucose $(\gamma=0.685)$, and fasting $C$-peptide $(\gamma=0.105)$, but negatively with postprandial insulin $(\gamma=-0.294)$, postprandial C-peptide $(\gamma=-0.264), \delta$ insulin $(\gamma=-$ 0.306), $\Delta$ C-peptide $(\gamma=-0.352)$, fasting $\beta$-cell responsiveness $(\gamma=-0.379)$, and postprandial $\beta$-cell responsiveness $(\gamma=-0.522 ; P<0.001)$. However, correlation with fasting insulin concentration was not significant. 
Table 3 Clinical characteristics according to the tertile of postprandial 2-h C-peptide level. Data are expressed as mean \pm s.D. Insulin, C-peptide, $M_{0}$, and $M_{1}$ values are described as median (range) values.

\begin{tabular}{|c|c|c|c|}
\hline Tertiles of PP 2-h C-peptide & Tertile 1 & Tertile 2 & Tertile 3 \\
\hline$n$ & 481 & 493 & 492 \\
\hline C-peptide range $(\mu \mathrm{g} / \mathrm{l})$ & $1.01-3.11$ & $3.12-4.45$ & $4.46-17.63$ \\
\hline Age (years) & $55.2 \pm 11.0$ & $55.1 \pm 11.0$ & $54.8 \pm 12.3$ \\
\hline Sex (female \%) & 47 & 44 & 43 \\
\hline Duration of diabetes (years) & $7.5 \pm 6.5$ & $4.8 \pm 5.4^{*}$ & $2.8 \pm 4.0^{\dagger \ddagger}$ \\
\hline BMI $\left(\mathrm{kg} / \mathrm{m}^{2}\right)$ & $24.3 \pm 3.0$ & $25.5 \pm 3.1^{*}$ & $26.3 \pm 3.2^{\dagger \ddagger}$ \\
\hline Fasting glucose $(\mathrm{mmol} / \mathrm{l})$ & $8.84 \pm 2.76$ & $7.95 \pm 2.09^{*}$ & $7.28 \pm 1.84^{\dagger \ddagger}$ \\
\hline PP 2-h glucose $(\mathrm{mmol} / \mathrm{l})$ & $13.28 \pm 4.95$ & $12.51 \pm 4.42^{*}$ & $11.87 \pm 3.92^{\dagger}$ \\
\hline $\mathrm{HbA}_{1 \mathrm{c}}(\%)$ & $8.3+1.8$ & $7.7 \pm 1.5^{\star}$ & $7.4+1.4^{\dagger \ddagger}$ \\
\hline Fasting insulin (pmol/l) & $34.3(4.8-153.5)$ & $46.9(9.9-219.0)^{*}$ & $62.7(11.3-234.8)^{\dagger \ddagger}$ \\
\hline PP 2-h insulin (pmol/l) & $114.6(17.7-528.3)$ & $225.6(42.8-790.0)^{\star}$ & $408.4(46.0-2152.5)^{\dagger \neq}$ \\
\hline Fasting C-peptide ( $\mu \mathrm{g} / \mathrm{l})$ & $1.22(0.54-2.91)$ & $1.53(0.70-3.91)^{\star}$ & $2.10(0.82-6.70)^{\dagger+}$ \\
\hline$\Delta$ Insulin $(\mathrm{pmol} / \mathrm{l})$ & $76.1(0.5-448.2)$ & $177.8(4.6-619.2)^{\star}$ & $341.6(3.6-1972.2)^{\dagger \ddagger}$ \\
\hline$\Delta$ C-peptide $(\mu \mathrm{g} / \mathrm{l})$ & $1.09(0.01-2.27)$ & $2.14(0.02-3.51)^{\star}$ & $3.69(0.70-14.84)^{\dagger \neq}$ \\
\hline $\bar{M}_{0}$ & $0.81(0.27-2.84)$ & $1.12(0.43-3.12)^{*}$ & $1.59(0.48-6.79)^{\dagger \ddagger}$ \\
\hline$M_{1}$ & $1.09(-88.0$ to 63.5$)$ & $2.25(-252.0-167.0)^{*}$ & $4.56(-481.0-372.0)^{\dagger \neq}$ \\
\hline HOMA-IR & $1.76(0.31-10.77)$ & $2.25(0.38-16.54)^{*}$ & $2.75(0.49-16.66)^{\Upsilon^{1+}}$ \\
\hline No. of tablet of sulfonylurea & $0.64 \pm 0.74$ & $0.51 \pm 0.66$ & $0.29 \pm 0.49^{\dagger \ddagger}$ \\
\hline No. of tablet of metformin & $1.21 \pm 1.26$ & $1.03 \pm 1.13$ & $0.68 \pm 1.00^{\dagger \neq}$ \\
\hline No. of tablet of $A G L$ & $0.33 \pm 0.84$ & $0.27 \pm 0.78$ & $0.16 \pm 0.60$ \\
\hline No. of tablet of TZD & $0.11 \pm 0.28$ & $0.10 \pm 0.26$ & $0.07 \pm 0.23$ \\
\hline No. of tablet of other OHA & $0.03 \pm 0.25$ & $0.04 \pm 0.30$ & $0.06 \pm 0.38$ \\
\hline Prevalence of insulin user (\%) & 8.7 & $1.8^{*}$ & $0.6^{\dagger}$ \\
\hline
\end{tabular}

BMI, body mass index; PP, postprandial; $M_{0}$, fasting $\beta$-cell responsiveness; $M_{1}$, postprandial $\beta$-cell responsiveness; HOMA-IR, homeostatic model assessment of insulin resistance; AGL, $\alpha$-glucose inhibitor; TZD, thiolidinedione; OHA, oral hypoglycemic agents. $P$ value was obtained from the ANOVA (post hoc and Tukey's test). ${ }^{\star} P<0.05$ between groups (tertile 1 versus tertile 2 ). ${ }^{\dagger} P<0.05$ between groups (tertile 1 versus tertile 3 ). ${ }^{\ddagger} P<0.05$ between groups (tertile 2 versus tertile 3$)$.

Table 4 Clinical characteristics according to the tertile of $\Delta$ C-peptide level. Data are expressed as mean \pm s.D. Insulin, C-peptide, $M_{0}$, and $M_{1}$ values are described as median (range) values.

\begin{tabular}{|c|c|c|c|}
\hline Tertiles of $\Delta \mathrm{C}$-peptide & Tertile 1 & Tertile 2 & Tertile 3 \\
\hline$n$ & 488 & 491 & 487 \\
\hline C-peptide range $(\mu \mathrm{g} / \mathrm{l})$ & $0.01-1.59$ & $1.60-2.70$ & $2.71-14.84$ \\
\hline Age (years) & $54.4 \pm 11.2$ & $55.5 \pm 11.3$ & $54.8 \pm 12.3$ \\
\hline Sex (female \%) & 47 & $\overline{44}$ & $\overline{43}$ \\
\hline Duration of diabetes (years) & $7.3 \pm 6.4$ & $5.1 \pm 5.6^{\star}$ & $2.8 \pm 4.0^{\dagger \ddagger}$ \\
\hline BMI $\left(\mathrm{kg} / \mathrm{m}^{2}\right)$ & $24.7 \pm 3.2$ & $25.3 \pm 3.0^{*}$ & $26.3 \pm 3.2^{\dagger \ddagger}$ \\
\hline Fasting glucose $(\mathrm{mmol} / \mathrm{l})$ & $9.04 \pm 2.65$ & $7.97 \pm 2.16^{*}$ & $7.28 \pm 1.84^{\dagger \ddagger}$ \\
\hline PP 2-h glucose (mmol/l) & $13.54 \pm 4.87$ & $12.56 \pm 4.58^{*}$ & $11.87 \pm 3.92^{\dagger \ddagger}$ \\
\hline $\mathrm{HbA}_{1 \mathrm{c}}(\%)$ & $8.5 \pm 1.7$ & $7.7 \pm 1.5^{\star}$ & $7.4 \pm 1.4^{\dagger \ddagger}$ \\
\hline Fasting insulin (pmol//) & $42.1(4.8-192.4)$ & $45.0(10.0-234.8)^{\star}$ & $55.2(9.9-228.3)^{\dagger \ddagger}$ \\
\hline PP 2-h insulin ( $\mathrm{pmol} / \mathrm{l})$ & $117.7(20.0-503.5)$ & $216.8(17.7-907.2)^{*}$ & $407.5(46.0-2152.5)^{\dagger \ddagger}$ \\
\hline Fasting C-peptide ( $\mu \mathrm{g} / \mathrm{l})$ & $1.39(0.54-5.12)$ & $1.51(0.70-5.70)^{\star}$ & $1.84(0.76-6.70)^{t+\frac{f}{7}}$ \\
\hline PP 2-h C-peptide $(\mu \mathrm{g} / \mathrm{l})$ & $2.48(1.01-5.82)$ & $3.65(2.50-8.05)^{*}$ & $5.58(3.53-17.63)^{\dagger \ddagger}$ \\
\hline$\Delta$ insulin $(\mathrm{pmol} / \mathrm{l})$ & $74.3(0.5-398.5)$ & $168.0(2.7-795.9)^{\star}$ & $344.0(3.6-1972.2)^{\dagger \ddagger}$ \\
\hline$M_{0}$ & $0.90(0.27-3.21)$ & $3.65(2.50-8.05)^{\star}$ & $1.45(0.48-4.42)^{\mathrm{ft}}$ \\
\hline$M_{1}$ & $1.00(-88.0-63.5)$ & $2.18(0.3-16.7)^{\star}$ & $4.77(-481.0-372.0)^{\dagger \ddagger}$ \\
\hline HOMA-IR & $2.29(0.31-16.54)$ & $2.18(0.33-16.66)$ & $2.38(0.38-10.80)$ \\
\hline No. of tablet of sulfonylurea & $0.65 \pm 0.76$ & $0.48 \pm 0.63^{*}$ & $0.27 \pm 0.47^{\dagger \neq}$ \\
\hline No. of tablet of metformin & $1.20 \pm 1.27$ & $1.01 \pm 1.12$ & $0.72 \pm 0.98^{\dagger \ddagger}$ \\
\hline No. of tablet of AGL & $0.36 \pm 0.89$ & $0.23 \pm 0.74$ & $0.15 \pm 0.57$ \\
\hline No. of tablet of TZD & $0.09 \pm 0.26$ & $0.12 \pm 0.29$ & $0.07 \pm 0.22$ \\
\hline No. of tablet of other $\mathrm{OHA}$ & $0.04 \pm 0.29$ & $0.03 \pm 0.25$ & $0.07 \pm 0.39$ \\
\hline Prevalence of insulin user (\%) & 9 & $1.0^{*}$ & $1.0^{\dagger}$ \\
\hline
\end{tabular}

BMI, body mass index; PP, postprandial; $M_{0}$, fasting $\beta$-cell responsiveness; $M_{1}$, postprandial $\beta$-cell responsiveness; HOMA-IR, homeostatic model assessment of insulin resistance; AGL, $\alpha$-glucose inhibitor; TZD, thiolidinedione; OHA, oral hypoglycemic agents. $P$ value was obtained from the ANOVA (post hoc and Tukey's test). ${ }^{\star} P<0.05$ between groups (tertile 1 versus tertile 2 ). ${ }^{\dagger} P<0.05$ between groups (tertile 1 versus tertile 3 ). ${ }^{\ddagger} P<0.05$ between groups (tertile 2 versus tertile 3$)$. 
A
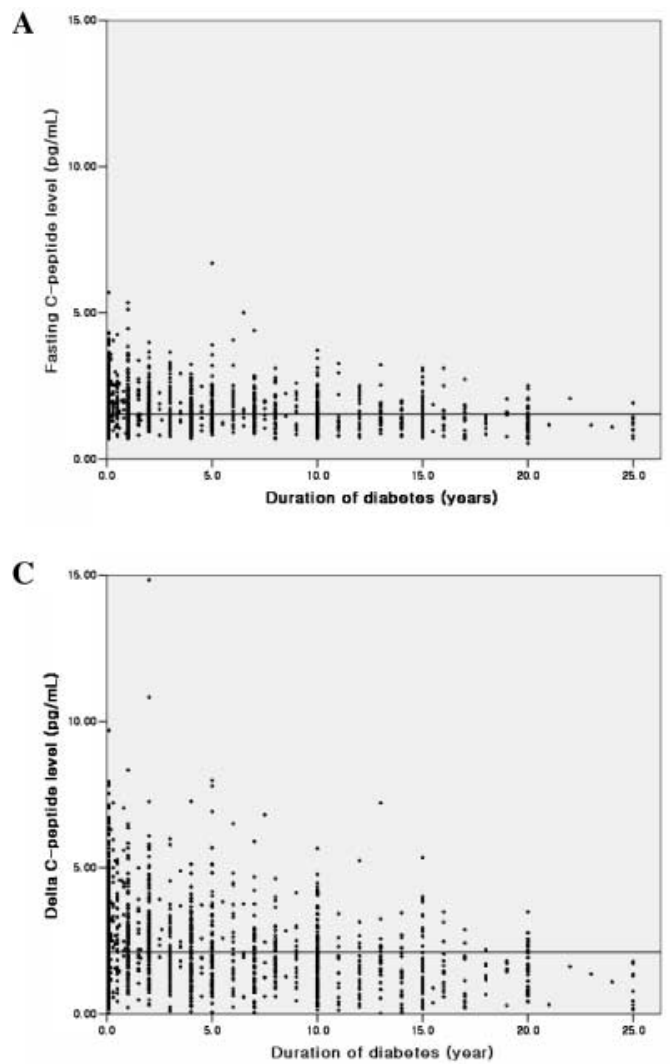

B

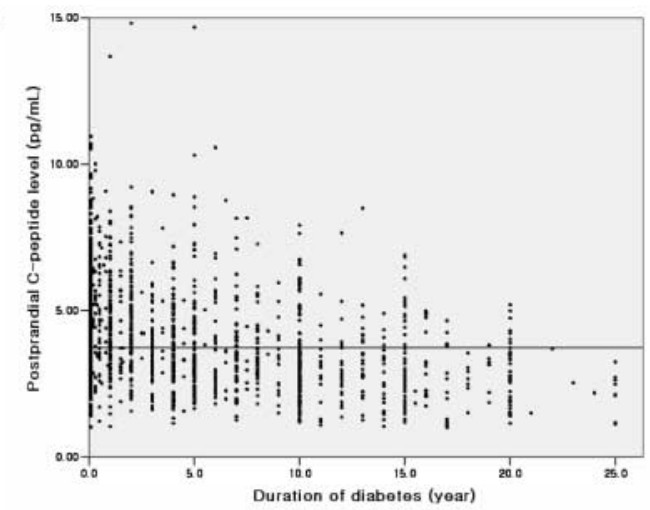

Figure 1 The distribution of C-peptide levels according to the duration of diabetes. (A) Fasting C-peptide, (B) postprandial 2-h C-peptide, and (C) $\Delta$ C-peptide. $\Delta$ C-peptide concentration was defined as the postprandial 2-h C-peptide concentration minus fasting C-peptide concentration. Horizontal lines indicate the median value of fasting C-peptide, postprandial 2-h C-peptide, and $\Delta$ C-peptide level respectively.

\section{Multiple regression analysis with $\mathrm{HbA}_{\mathrm{Ic}}$ as a dependent variable}

In stepwise multiple regression analysis, $M_{0}, M_{1}$, and HOMA-IR emerged as predictors of $\mathrm{HbA}_{1 \mathrm{c}}$. When $M_{1}$ was used as a predictor of $\mathrm{HbA}_{1 \mathrm{c}}, R^{2}$ was 0.272 . When $M_{1}$ and HOMA-IR were used as predictors of $\mathrm{HbA}_{1}$, $R^{2}$ was 0.328 . When $M_{1}$, HOMA-IR, and $M_{0}$ were used as predictors of $\mathrm{HbA}_{1 \mathrm{c}}, R^{2}$ was $0.408 . M_{1}$ explained $27.2 \%$ of the variation in the change of $\mathrm{HbA}_{1 \mathrm{c}}$. The addition of HOMA-IR to $M_{1}$ explained an additional $5.6 \%$ of the variation in the change of $\mathrm{HbA}_{1 \mathrm{c}}$. The addition of $M_{0}$ to $M_{1}$ and HOMA-IR explained an additional $8 \%$ of the variation in the change of $\mathrm{HbA}_{1 \mathrm{c}}$ than $\mathrm{M}_{1}$ plus HOMA-IR.

\section{Discussion}

Failure of pancreatic $\beta$-cells to secrete adequate insulin to maintain normoglycemia is a prerequisite in the development of type- 2 diabetes. Therefore, it is important to evaluate pancreatic $\beta$-cell function, which may be a good index of predicting glycemic control and prognosis. The meal tolerance test is more physiological test to measure the pancreatic $\beta$-cell function, and it can also distinguish the diverse range response of pancreas (1).

The present results showed that fasting C-peptide, $\Delta$ C-peptide, postprandial $C$-peptide, fasting $\beta$-cell responsiveness, and postprandial $\beta$-cell responsiveness were decreased, but fasting glucose, postprandial glucose, and $\mathrm{HbA}_{1 \mathrm{c}}$ values were increased with the increase of the duration of diabetes. These results indicate that fasting and postprandial $\beta$-cell functions and the degree of glycemic control have deteriorated with the duration of diabetes in type-2 diabetic patients, indicating type- 2 diabetes is a progressive disease as shown in the previous study (2). In type-2 diabetic patients, $\beta$-cell function assessed by the HOMA method deteriorated in subjects on diet therapy. In subjects on continuing sulfonylurea therapy, $\beta$-cell function assessed by the HOMA method increased in the first year but subsequently decreased at 6 years (2). Furthermore, fasting and postprandial 1-h C-peptide levels decreased significantly with the duration of diabetes in type-2 diabetic patients (15). 
Our result showed that postprandial insulin secretion was decreased with the increase in the duration of diabetes is in good agreement with those studies with type-1 diabetes (16). Among 2432 patients diagnosed as type-1 diabetes after the age of 18 years, the patients with 1-5 years duration at the time of eligibility screening, stimulated C-peptide was $\geq 0.2 \mathrm{nmol} / \mathrm{l}$ in $48 \%$ of the cases and $>$ $0.5 \mathrm{nmol} / \mathrm{l}$ in $15 \%$ of the cases; whereas for those with >5-15 years duration, stimulated C-peptide was $\geq 0.2 \mathrm{nmol} / \mathrm{l}$ in $8 \%$ and $>0.5 \mathrm{nmol} / \mathrm{l}$ in $2 \%$ of the cases (16).

In a study for the prevention of type- 1 diabetes, it was found no fall of C-peptide (peak and area under the curve) production over time in non-progressors, compared with progressors, regardless of type of tolerance testing employed (mixed meal, oral, or i.v.) (17). These results suggest that the preservation of C-peptide production in the prediabetic period appears to indicate non-progression to clinical disease and may serve as a new surrogate for determining response to preventative efforts. Based on the earlier descriptions, postprandial C-peptide level seems to be used as a progression marker of diabetes not only for the group with high risk of diabetes and type- 1 diabetes, but also for the group with type-2 diabetes.

The results of this study showed that the decrease of postprandial C-peptide and $\beta$-cell responsiveness, which represent postprandial $\beta$-cell function, was more prominent than fasting $C$-peptide and $\beta$-cell responsiveness with the increase of the duration of diabetes. These results are consistent with the results obtained with the newly presenting type-2 diabetic patients (9). The postprandial $\beta$-cell responsiveness was reduced by about $80 \%$ compared with BMI-matched healthy subjects, whereas fasting $\beta$-cell responsiveness was reduced by approximately $50 \%$ in the newly presenting type-2 diabetic subjects. Taken together, these results suggest that the reduction of postprandial $\beta$-cell responsiveness was more prominent than fasting $\beta$-cell responsiveness not only in the early stage of type-2 diabetes, but also in the late stage of type-2 diabetes.

In this study, $\mathrm{HbA}_{1 \mathrm{c}}$ value of patients with the highest tertile of postprandial C-peptide value was significantly lower than in other groups although they had taken the lowest amount of oral hypoglycemic agents, which is consistent with the study on type-1 diabetes mellitus (18). Patients whose C-peptide levels were increased to over $0.20 \mathrm{pmol} / \mathrm{ml}$ had better metabolic control, and their $\mathrm{HbA}_{1 \mathrm{c}}$ and fasting and postprandial glucose values were lower although they received less insulin. Furthermore, C-peptide values as low as $0.10-0.20 \mathrm{pmol} / \mathrm{ml}$ may also have an impact on diabetic management, since patients in this group required less exogenous insulin to achieve the same level of glycemic control, as those whose stimulated levels were $0.05 \mathrm{pmol} / \mathrm{ml}$ or less (18). In other words, even though insulin-secretory capacity is absolutely decreased in type-1 diabetes, peak postprandial C-peptide concentration is important for glycemic control.

In this study, although $\mathrm{HbA}_{1 \mathrm{c}}$ was correlated with both fasting and postprandial $\beta$-cell responsiveness, it was more closely correlated with postprandial $\beta$-cell responsiveness. Indeed, postprandial insulin deficiency is the most plausible factor underlying elevated fasting plasma glucose, $\mathrm{HbA}_{1 \mathrm{c}}$ and glucose responses to meal in newly presenting type- 2 diabetic patients (9), implying that the postprandial $\beta$-cell responsiveness is the most important factor in glycemic control not only in the newly presenting diabetic patients, but also in the patients with diverse durations of diabetes.

Type-2 diabetes is characterized by defects in both insulin secretion and insulin sensitivity (19). While hyperglycemia can result from both insulin resistance and $\beta$-cell dysfunction, there has been much debate over the past few decades regarding the relative importance of these two abnormalities in the development of type-2 diabetes (20-23). In this study, $M_{1}$ and $M_{0}$ explained 27.2 and $8.0 \%$ respectively, of the variation in the chance of $\mathrm{HbA}_{1 \mathrm{c}}$, while HOMA-IR explained $5.6 \%$ of variation. These results suggest that, although insulin resistance is a crucial factor in glycemic control, insulin secretion, especially postprandial $\beta$-cell responsiveness, may be more important in the regulation of glycemic control than insulin resistance. However, since there are various ethnic differences in insulin resistance and $\beta$-cell function (24), more studies are required to assess the role of insulin secretion, postprandial $\beta$-cell responsiveness in particular, and peripheral insulin resistance in glycemic control in various ethnic population.

The limitation of our study is its cross-sectional nature. Nevertheless, this constitutes the largest scaled study on the fasting and postprandial insulin secretion, which was examined by the meal tolerance test, in type2 diabetic patients, whose duration of diabetes was varied. In summary, fasting and postprandial insulin secretions were found to decrease as the duration of diabetes was increased, and particularly, postprandial insulin secretion was more prominently decreased. Furthermore, in comparison with fasting $\beta$-cell responsiveness, postprandial $\beta$-cell responsiveness was observed to exert greater effect on glycemic control in type-2 diabetes mellitus.

\section{Acknowledgements}

This work was supported by a grant no. R13-2002054-01 002-0 (2002) from the Basic Research Program of the Korea Science \& Engineering Foundation. 


\section{References}

1 Hovorka R, Chassin L, Luzio SD, Playle R \& Owens DR. Pancreatic $\beta$-cell responsiveness during meal tolerance test: model assessment in normal subjects and subjects with newly diagnosed noninsulindependent diabetes mellitus. Journal of Clinical Endocrinology and Metabolism $1998 \mathbf{8 3} 744-750$.

2 UK Prospective Diabetes Study Group. UK prospective diabetes study 16: overview of 6 years' therapy of type II diabetes: a progressive disease. Diabetes 199544 1249-1258.

3 Borona E, Calcaterra F, Lombardi S, Bonfante N, Formentini G, Bonadonna RC \& Muggeo M. Plasma glucose levels throughout the day and $\mathrm{HbA} 1 \mathrm{c}$ interrelationships in type 2 diabetes. Diabetes Care 200124 2023-2029.

4 Avignon A, Radauceanu A \& Monnier L. Nonfasting plasma glucose is a better marker of diabetic control than fasting plasma glucose in type 2 diabetes. Diabetes Care $1997201822-1826$.

5 Bouma M, Dekker JH, de Sonnaville JJ, Van der Does FE, de Vries H, Kriegsman DM, Kostense PJ, Heine RJ \& van Eijk JT. How valid is fasting plasma glucose as a parameter of glycemic control in noninsulin-using patients with type 2 diabetes? Diabetes Care 2004 22 904-907.

6 Verges B. The impact of regulation of postprandial glucose in practice. Diabetes and Metabolism 199925 22-25.

7 de Veciana M, Major CA, Morgan MA, Asrat T, Toohey JS, Lien JM \& Evans AT. Postprandial versus preprandial blood glucose monitoring in women with gestational diabetes mellitus requiring insulin therapy. New England Journal of Medicine 1995333 1237-1241.

8 Feinglos MN, Thacker CH, English J, Bethel MA \& Lane JD. Modification of postprandial hyperglycemia with insulin lispro improves glucose control in patients with type 2 diabetes. Diabetes Care 199720 1539-1542.

9 Albarrak AI, Luzio SD, Chassin LJ, Playle RA, Owens DR \& Hovorka R. Associations of glucose control with insulin sensitivity and pancreatic $\beta$-cell responsiveness in newly presenting type 2 diabetes. Journal of Clinical Endocrinology and Metabolism 2002 87 198-203.

10 Inukai K, Watanabe M, Nakashima Y, Sawa T, Takata N, Tanaka M, Kashiwabara H, Yokota K, Suzuki M, Kurihara S, Awata T \& Katayama S. Efficacy of glimepiride in Japanese type 2 diabetic subjects. Diabetes Research and Clinical Practice 2005 $68250-257$.

11 Vichayanrat A, Ploybutr S, Tunlakit M \& Watanakejorn P. Efficacy and safety of voglibose in comparison with acarbose in type 2 diabetic patients. Diabetes Research and Clinical Practice 2002 55 99-103.

12 Aronoff S, Rosenblatt S, Braithwaite S, Egan JW, Mathisen AL \& Schneider RL. Pioglitazone hydrochloride monotherapy improves glycemic control in the treatment of patients with type 2 diabetes: a 6-month randomized placebo-controlled dose-response study. The Pioglitazone 001 Study Group. Diabetes Care 2000 23 1605-1611.
13 Fonseca V, Rosenstock J, Patwardhan R \& Salzman A. Effect of metformin and rosiglitazone combination therapy in patients with type 2 diabetes mellitus: a randomized controlled trial. JAMA 2000283 1695-1702.

14 Matthews DR, Hosker JP, Rudenski AS, Naylor BA, Treacher DF \& Turner RC. Homeostasis model assessment: insulin resistance and beta-cell function from fasting plasma glucose and insulin concentrations in man. Diabetologia $1985 \mathbf{2 8} 412-419$.

15 Haupt E, Haupt A, Herrmann R, Benecke-Timp A, Vogel H \& Walter C. The KID Study V: the natural history of type 2 diabetes in younger patients still practicing a profession. Heterogeneity of basal and reactive $\mathrm{C}$-peptide levels in relation to BMI, duration of disease, age and HbA1c. Experimental and Clinical Endocrinology and Diabetes 1999107 236-243.

16 Palmer JP, Fleming GA, Greenbaum CJ, Herold KC, Jansa LD, Kolb H, Lachin JM, Polonsky KS, Pozzilli P, Skyler JS \& Steffes MW. $\mathrm{C}$-peptide is the appropriate outcome measure for type 1 diabetes clinical trials to preserve $\beta$-cell function. Report of an ADA workshop, 21-22 october 2001. Diabetes 200453 250-264.

17 Schatz D, Cuthbertson D, Atkinson M, Saizler MC, Winter W, Muir A, Silverstein J, Cook R, Maclaren N, She JX, Greenbaum C \& Krischer J. Preservation of C-peptide secretion in subjects at high risk of developing type 1 diabetes mellitus - a new surrogate measure of non-progression? Pediatric Diabetes 20045 72-79.

18 The DCCT Research Group. Effects of age, duration and treatment of insulin-dependent diabetes mellitus on residual beta-cell function: observations during eligibility testing for the Diabetes Control and Complications Trial (DCCT). Journal of Clinical Endocrinology and Metabolism 199765 30-36.

19 DeFronzo RA \& Prato SD. Insulin resistance and diabetes mellitus. Journal of Diabetes and its Complications $199610243-245$.

20 DeFronzo RA \& Ferrannini E. Insulin resistance. A multifaceted syndrome responsible for NIDDM, obesity, hypertension, dyslipidemia, and atherosclerotic cardiovascular disease. Diabetes Care 199114 173-194.

21 Kruszynska YT \& Olefsky JM. Cellular and molecular mechanisms of non-insulin dependent diabetes mellitus. Journal of Investigative Medicine $1996 \mathbf{4 4} 413-428$.

22 Porte D, Jr. Banting lecture 1990. Beta-cells in type II diabetes mellitus. Diabetes 199140 166-180.

23 Kahn SE. The importance of B-cell failure in the development and progression of type 2 diabetes. Journal of Clinical Endocrinology and Metabolism 200186 4047-4058.

24 Torrens JI, Skurnick J, Davidow AL, Korenman SG, Santoro N, Soto-Greene M, Lasser N \& Weiss G. Ethnic differences in insulin sensitivity and beta-cell function in premenopausal or early perimenopausal women without diabetes: the Study of Women's Health Across the Nation (SWAN). Diabetes care 200427 354-361.

Received 4 March 2006

Accepted 10 July 2006 